\title{
The Functions of the Stock Market and the Fallacies of Shareholder Value
}

\author{
William Lazonick $^{*+}$
}

\section{Working Paper No. 58}

\author{
June 3, 2017 \\ (revised July 20, 2017)
}

\begin{abstract}
Conventional wisdom has it that the primary function of the stock market is to raise cash for companies for the purpose of investing in productive capabilities. The conventional wisdom is wrong. Academic research on sources of corporate finance shows that, compared with other sources of funds, stock markets in advanced countries have been insignificant suppliers of capital for corporations. The purpose of this essay is to build a rigorous and relevant conception of the evolving role of the stock market in the U.S. corporate economy. In fact, the functions of the stock market go well beyond "cash" to include four other functions, which can be summarized as "control," "creation," "combination," and "compensation." In this paper, I argue, based on historical evidence, that in the growth of the U.S. economy the key function of the stock market was control. Specifically, the stock market enabled the separation of managerial control over the allocation of corporate resources from the ownership of the company's shares. Yet, assuming that the key function of the stock market

\footnotetext{
* University of Massachusetts Lowell and the Academic-Industry Research Network. william.lazonick@gmail.com

${ }^{+}$This paper has been prepared for a volume What Next for Corporate Governance? edited by Ciaran Driver and Grahame Thompson. Funding for this research came from the Institute for New Economic Thinking, the European Union Horizon 2020 Project No. 649186 on Innovation-Fuelled Sustainable and Inclusive Growth, and the Korea Economic Research Institute. I acknowledge the comments of Jang-Sup Shin, Matt Hopkins, and Ken Jacobson, with whom I am doing research on the imbalance between value creation and value extraction in the U.S. economy.
} 
is cash, economists known as agency theorists see this separation of control from ownership as the "original sin" of American capitalism, and argue that the evils of managerial control can be overcome by compelling corporate managers as "agents" to maximize the value of corporate shareholders as "principals."

What is missing from the agency-theory argument is a theory of the value-creating firm, or what I call a "theory of innovative enterprise." The value-creation process requires three social conditions of innovative enterprise: strategic control, organizational integration, and financial commitment. The functions of the stock market may support the types of strategic control, organizational integration, and financial commitment that can result in the generation of high-quality products at low unit costs - the economic definition of innovative enterprise. It is possible, however, that the functions of the stock market may undermine the types of strategic control, organizational integration, and financial commitment that the innovation process requires.

In this paper, I provide a brief overview of the role of the control function of the stock market in supporting innovative enterprise in the historical rise to dominance of U.S. managerial capitalism from the early decades of the twentieth century. Then I elaborate the five functions of the stock market - control, cash, creation, combination, and compensation - in terms of the ways in which, from the perspective of the theory of innovative enterprise, each function can support value creation or, alternatively, empower value extraction. I then turn to a discussion of the evolving roles of the five functions of the stock market in major U.S. business corporations over the past century. The concluding section draws on the history of the actual functions of U.S. stock markets to critique the dominant ideology that, for the sake of superior economic performance, a company should be run to "maximize shareholder value" (MSV). I indicate how MSV undermines the social conditions of innovative enterprise: strategic control, organizational integration, and financial commitment.

JEL Codes: G35, J33, L21, L22, L25, L26, N21, N22, 016, O3

Keywords: Corporate governance, stock market, maximize shareholder value (MSV), stock-based compensation, stock buybacks, innovation, speculation, manipulation, innovation theory, agency theory, shareholder value ideology 


\section{What does the stock market do?}

Conventional wisdom has it that the primary function of the stock market is to raise cash for companies for the purpose of investing in productive capabilities. The conventional wisdom is wrong. Academic research on sources of corporate finance shows that, compared with other sources of funds, stock markets in advanced countries have been insignificant suppliers of capital for corporations. ${ }^{1}$

Indeed, in the United States, the escalating growth of stock repurchases as a mode of distributing cash to shareholders over the past three decades has made corporations massive suppliers of funds to the stock market, rather than vice versa. ${ }^{2}$ Figure 1 shows data for net equity issues - new corporate stock issues minus outstanding stock retired through stock repurchases and merger and acquisition activity - in the United States from 1946 through 2016. Since the mid-1980s net equity issues for nonfinancial corporations have been generally negative, and since the mid-2000s massively negative.

Figure 1: Net equity issues, U.S. nonfinancial and financial companies, 1946-2016 400

200

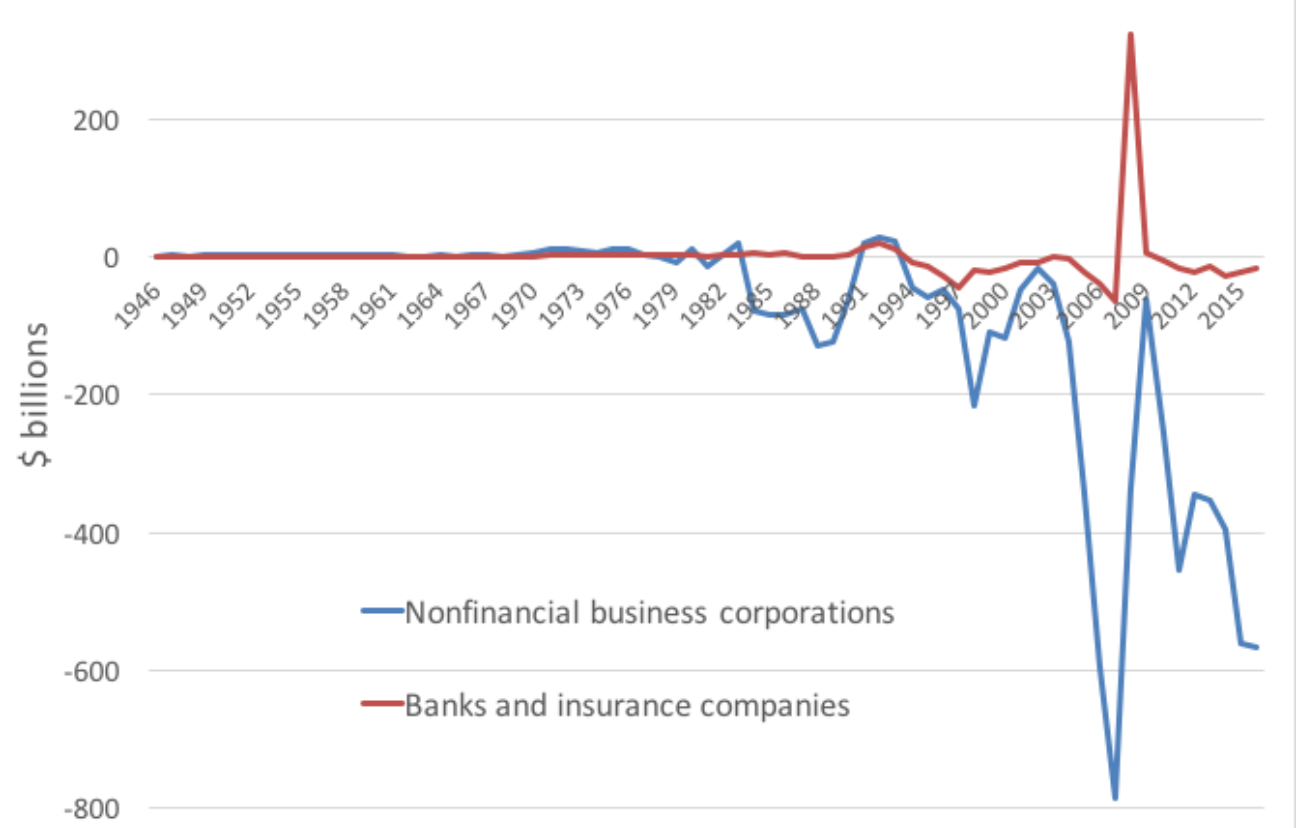

Source: Board of Governors of the Federal Reserve System, Federal Reserve Statistical Release Z.1,

"Financial Accounts of the United States: Flow of Funds, Balance Sheets, and Integrated

Macroeconomic Accounts," Table F-223: Corporate Equities, March 9, 2017, at

https://www.federalreserve.gov/releases/z1/current/

Over the decade 2007-2016 net equity issues of nonfinancial corporations averaged -\$412 billion per year. ${ }^{3}$ In 2016 net equity issues were $-\$ 568$ billion. Over the past three decades, in aggregate,

1 Colin Mayer, "New Issues in Corporate Finance," European Economic Review 32, 1988: 1167-83; Jenny Corbett and Tim Jenkinson, "The Finance of Industry: An International Comparison," Journal of the Japanese and International Economy, 10, 1996: 71-96; Franklin Allen and Douglas Gale, Comparing Financial Systems: A Survey, MIT Press, 2001, ch. 2.

2 William Lazonick, "The New Economy Business Model and the Crisis of U.S. Capitalism," Capitalism and Society, 4, 2, 2009, article 4; William Lazonick, "The Value-Extracting CEO: How Executive Stock-Based Pay Undermines Investment in Productive Capabilities," Institute for New Economic Thinking Working Paper No. 54, December 4, 2016, at https://www.ineteconomics.org/research/research-papers/the-value-extracting-ceo-how-executive-stock-based-payundermines-investment-in-productive-capabilities.

3 The spike in equity issues for financial corporations in 2009 occurred when some of the largest among them sold stock to the U.S. government in the financial-crisis bailout. The banks that were bailed out had been major repurchasers of their own stock in the years before the financial meltdown. See William Lazonick, "Everyone is paying the price for share buy- 
dividends have tended to increase as a proportion of corporate profits. Yet in 1997, for the first time, buybacks surpassed dividends in the U.S. corporate economy and, even with dividends increasing, have far exceeded them in recent stock-market booms. ${ }^{4}$

Using the data in Figure 1, the first data column of Table 1 shows the amounts of net equity issues by non-financial corporations, decade by decade, from 1946 to 2015, in 2015 dollars. For the first three decades after World War II, net equity issues were moderately positive in the corporate economy as a whole. In the following decades, however, net equity issues became increasingly negative (even after adjusting for inflation). As a gauge of their growing importance in the economy, the second data column of Table 1 shows net equity issues as a proportion of GDP.

Table 1. Net equity issues by non-financial corporations in the U.S. economy, by decade in 2015 dollars, and as a percent of GDP

\begin{tabular}{|l|c|c|}
\hline & $\begin{array}{c}\text { Net equity issues, } \\
\text { U.S. non-financial } \\
\text { corporations } \\
\text { 2015\$ billions }\end{array}$ & $\begin{array}{c}\text { Net equity } \\
\text { issues as } \\
\text { \% of GDP }\end{array}$ \\
\hline $\mathbf{1 9 4 6 - 1 9 5 5}$ & 143.2 & 0.56 \\
\hline $\mathbf{1 9 5 6 - 1 9 6 5}$ & 110.9 & 0.30 \\
\hline $\mathbf{1 9 6 6 - 1 9 7 5}$ & 316.0 & 0.58 \\
\hline $\mathbf{1 9 7 6 - 1 9 8 5}$ & -290.9 & -0.40 \\
\hline $\mathbf{1 9 8 6 - 1 9 9 5}$ & $-1,002.5$ & -1.00 \\
\hline $\mathbf{1 9 9 6 - 2 0 0 5}$ & $-1,524.4$ & -1.09 \\
\hline $\mathbf{2 0 0 6 - 2 0 1 5}$ & $-4,466.6$ & -2.65 \\
\hline
\end{tabular}

Sources: Net equity issues data is the same as in Figure 1 (see note 3), adjusted to 2015 U.S. dollars, using the consumer price index in Council of Economic Advisors, Economic Report of the President 2017, January 2017, Table B-10, at http://www.presidency.ucsb.edu/economic_reports/2017.pdf.

Over the past three decades, in aggregate, U.S. stock markets, of which the New York Stock Exchange (NYSE) and the National Association of Securities Dealers Automated Quotation (NASDAQ) exchange are by far the most important, have extracted trillions of dollars from business corporations in the form of stock buybacks. Of course, some companies raise funds on the stock market, particularly when they are doing initial public offerings (IPOs). But these amounts tend to be relatively small, swamped overall by the stock repurchases that have made net equity issues hugely negative. Moreover, when the most successful startups become major enterprises, often employing tens of thousands of people, these companies tend to become major repurchasers of their stock.

I have called this massive flow of cash out of companies the legalized looting of the U.S. industrial corporation. ${ }^{5}$ Most economists, however, adhere to agency theory, which contends that, for the sake of economic efficiency, the purpose of the corporation is to "maximize shareholder value" (MSV), and hence they would portray this flow of cash out of companies to the stock market as a "return" of capital to shareholders who will then reallocate capital to its best alternative uses. MSV, however, lacks a theory of the value-creating, or innovative, enterprise, and hence cannot explain how "best alternative uses" come into existence, and in particular the role of organizations rather than markets in creating value in the economy. ${ }^{6}$ Moreover, corporations cannot "return" capital to shareholders if

backs," Financial Times, September 26, 2008, p. 25; William Lazonick, “The buyback boondoggle," BusinessWeek, August $24 \& 31,2009$, p. 96.

${ }^{4}$ William Lazonick, "Stock Buybacks: From Retain-and-Reinvest to Downsize-and-Distribute," Center for Effective Public Management, Brookings Institution, April 2015, pp. 10-11, at http://www.brookings.edu/research/papers/2015/04/17stock-buybacks-lazonick; Lazonick, "The Value-Extracting CEO."

5 Lazonick, "The Value-Extracting CEO."

${ }^{6}$ William Lazonick, Business Organization and the Myth of the Market Economy, Cambridge University Press, 1991; William Lazonick, "The Theory of the Market Economy and the Social Foundations of Innovative Enterprise," Economic and Industrial Democracy, 24, 1, 2003: 9-44; William Lazonick, "Innovative Enterprise or Sweatshop Economics? In Search of Foundations of Economic Analysis," Challenge, 59, 2, 2016: 65-114. 
those shareholders never provided corporations with capital in the first place. This essay is dedicated to the proposition that MSV misunderstands the historical role that the stock market has played in the evolution of the U.S. business corporation and its contribution to economic performance. A correct understanding of the evolving functions of the stock market in the U.S. corporate economy supports the hypothesis that its current functioning is a prime source of employment instability, income inequity, and slowing productivity. ${ }^{7}$

The purpose of this essay is to build a rigorous and relevant conception of the evolving role of the stock market in the U.S. corporate economy. In fact, the functions of the stock market go well beyond "cash" to include four other functions, which can be summarized as "control," "creation," "combination," and "compensation". These five functions of the stock market can be summarized as follows:

- Control: A stock-market listing enables the separation of managerial control over corporate resource-allocation decisions from ownership of the publicly-traded shares of the corporation.

- Cash: Through an IPO and, possibly, one or more secondary public offerings, the stock market can be a source of corporate finance, but through distributions to shareholders it may perform a negative cash function.

- Creation: The prospect that a start-up company will be able to do an initial public offering (IPO) on the stock market within a three-to-five-year timeframe can induce private equity (i.e., venture capital) to invest in new firm formation.

- Combination: The stock market enables corporate shares to function as a currency, instead of cash, to finance mergers and acquisitions.

- Compensation: A stock-market listing enables corporate shares to function as a currency, instead of cash, for employee remuneration in the forms of stock purchase plans, stock options, or stock awards.

In this paper, I argue, based on historical evidence, that in the growth of the U.S. economy the key function of the stock market was control. Specifically, the stock market enabled the separation of managerial control over the allocation of corporate resources from the ownership of the company's shares. In what the business historian Alfred Chandler called "the managerial revolution," the operation and performance of major U.S. business enterprises depended on the decisions of professional salaried career personnel, with share ownership of these corporations in the hands of households as savers who were willing to hold corporate shares for the sake of a dividend income that could be secured without their active participation in corporate decision-making. ${ }^{8}$ Indeed, in the Chandlerian managerial revolution, which was largely complete in the United States by the 1920s, the separation of control from ownership occurred because of the need to overcome the managerial constraint on the growth of the firm that was inherent in the integration of ownership and control, and not because of (as is typically assumed) the need to fund that growth by selling ownership stakes to public shareholders.

Yet, assuming that the key function of the stock market is cash, economists known as agency theorists see this separation of control from ownership as the "original sin" of American capitalism, and argue that the evils of managerial control can be overcome by compelling corporate managers as "agents" to maximize the value of corporate shareholders as "principals." ${ }^{9}$ In the era of the dominance of managerial control that stretched from the 1920 s into the 1980 s, however, the operation and performance of major U.S. business corporations enabled the United States to emerge as the world's largest and most powerful economy. Moreover, in the three decades after the end of World War II,

\footnotetext{
7 William Lazonick, "Labor in the Twenty-First Century: The Top $0.1 \%$ and the Disappearing Middle Class," in Christian E. Weller, ed., Inequality, Uncertainty, and Opportunity: The Varied and Growing Role of Finance in Labor Relations, Cornell University Press, 2015: 143-192.

8 Alfred D. Chandler, Jr., The Visible Hand: The Managerial Revolution in American Business, Harvard University Press, 1977.

9 See Michael C. Jensen, “Agency Costs of Free Cash Flow, Corporate Finance, and Takeovers," American Economic Review, 76, 2, 1986: 323-329.
} 
managerial control over the allocation of corporate resources contributed to relatively stable and equitable growth in the economy as a whole. ${ }^{10}$

What is missing from the agency-theory argument is a theory of the value-creating firm, or what I call a "theory of innovative enterprise." innovative enterprise: strategic control, organizational integration, and financial commitment.

- Strategic control: a set of relations that gives decision-makers the power to allocate the firm's resources to confront uncertainty by transforming technologies and accessing markets to generate higher quality, lower cost products;

- Organizational integration: a set of relations that creates incentives for people in a hierarchical and functional division of labor to apply their skills and efforts to engage in collective learning;

- Financial commitment: a set of relations that secures finance to sustain the cumulative learning process from the time when investments in productive capabilities are made until innovative products generate financial returns.

The functions of the stock market may support the types of strategic control, organizational integration, and financial commitment that can result in the generation of high-quality products at low unit costs - the economic definition of innovative enterprise. ${ }^{12}$ The functions of the stock market may enable executives with the abilities and incentives to invest in innovation to exercise strategic control over the allocation of corporate resources. They may enable incentives that integrate employees into the collective and cumulative learning processes that are the essence of innovation. They may enable the enterprise to control sources of finance that will sustain the innovation process until it can generate financial returns. It is possible, however, that the functions of the stock market may undermine the types of strategic control, organizational integration, and financial commitment that the innovation process requires. And it may be that an ideology of corporate governance that misconceives the functions of the stock market will legitimize its operation in ways that erode the social conditions of innovative enterprise. It is my contention that agency theory, with its ideology that, for the sake of superior efficiency, companies should be run to "maximize shareholder value" has had precisely this deleterious impact on the innovative performance of the U.S. business corporation over the past three decades.

In the next section of this paper, I provide a brief overview of the role of the control function of the stock market in supporting innovative enterprise in the historical rise to dominance of U.S. managerial capitalism from the early decades of the twentieth century. Then I elaborate the five functions of the stock market - control, cash, creation, combination, and compensation-in terms of the ways in which, from the perspective of the theory of innovative enterprise, each function can support value creation or, alternatively, empower value extraction. I then turn to a discussion of the evolving roles of the five functions of the stock market in major U.S. business corporations over the past century. The concluding section draws on the history of the actual functions of U.S. stock markets to critique the dominant ideology that, for the sake of superior economic performance, a company should be run to "maximize shareholder value." I indicate how MSV undermines the social conditions of innovative enterprise: strategic control, organizational integration, and financial commitment.

\footnotetext{
${ }^{10}$ Lazonick, "Labor in the Twenty-First Century."

${ }^{11}$ William Lazonick, "The Chandlerian Corporation and the Theory of Innovative Enterprise," Industrial and Corporate Change, 19, 2, 2010: 317-349; William Lazonick, "Innovative Enterprise and Shareholder Value," Law and Financial Markets Review, 8, 1, 2014: 52-64; William Lazonick, "The Theory of Innovative Enterprise: Foundation of Economic Analysis," AIR Working Paper, August 2015, at www.theAIRnet.org; William Lazonick, "Innovative Enterprise or Sweatshop Economics?".

12 Lazonick, "The Theory of Innovative Enterprise."
} 


\section{The control function, innovative enterprise, and U.S. economic growth}

In historical perspective, it is wrong to assume that the primary role of the stock market for the companies that issue shares was to raise cash. ${ }^{13}$ Going back to the rise of big business in the United States in the late nineteenth century, the primary function of the stock market was not to raise cash for corporate investment but rather to enable the owner-entrepreneurs and their private-equity partners who had led the building of major business enterprises to exit their investments through what we now call an initial public offering (IPO). This process separated the ownership of corporate shares and managerial control over the allocation of corporate resources, giving rise to managerial capitalism.

Central to the process of separating share ownership and managerial control in the rise of big business in the United States was the Great Merger Movement of the 1890s and early 1900s. The most enduring mergers proved to be in those industries in which continuous product and process innovation and high-speed utilization of production and distribution facilities were most important for sustaining competitive advantage. And the most successful combinations were ones in which the ownerentrepreneurs of the leading firms had invested in superior managerial capabilities for developing and utilizing productive resources. When the original owner-entrepreneurs retired from the industrial scene, there were experienced and committed executives ready, willing, and able to take their places in positions of strategic control.

Here is how it worked. Wall Street investment banks-J. P. Morgan foremost among themunderwrote the merger of a group of firms in an industry to create a business entity with a large market share that could be floated on the NYSE. The underwriting syndicate issued corporate bonds to pay the owner-entrepreneurs and their private equity partners for their ownership stakes, and then sold the listed shares to the public over time as the syndicate saw fit. The result was the transfer of ownership of corporate assets from the original owner-entrepreneurs to an increasingly widely distributed population of shareholders. As a result, beginning in the $1890 \mathrm{~s}$ a national market in industrial securities emerged. ${ }^{14}$ Contrary to conventional wisdom, the rise of the large-scale industrial corporation created the stock market, not vice versa. ${ }^{15}$

The enhanced market dominance of the new combinations plus the backing of Wall Street encouraged private wealthholders to invest in industrial stocks. By the 1920s, the NYSE had become a highly liquid market in industrial securities, thus making shareholding attractive to households that simply wanted to place their savings in outstanding financial securities that promised an income and, if and when a household should decide to sell its shares, a possible capital gain. Beyond the payment of the market price to purchase the stock, public shareholding offered limited liability and did not require the shareholder to make any further commitments of time, effort, or finance to the firms in which he or she had bought shares. And the existence of a liquid stock market meant that, at any time, these shareholders could easily monetize this financial asset by instructing a broker to sell some or all of the shares—what became known as the "Wall Street walk."

By instilling confidence in shareholders, the NYSE's stringent listing requirements in terms of a profitability record and capital assets enhanced the liquidity of the exchange. Yet underpinning the liquidity of the NYSE in the 1920s, and rendering volatile the stock prices of even the most profitable and dominant companies, was the existence of the call-loan market that enabled stock-market speculators to buy stock on margin, putting up only five percent of their own funds and borrowing the rest. During the speculative boom of the late 1920s, which culminated in the Great Crash in October

\footnotetext{
${ }^{13}$ For an elaboration of this argument and bibliographic references, see William Lazonick, "Alfred Chandler's Managerial Revolution: Developing and Utilizing Productive Resources," in Morgen Witzel, and Malcolm Warner, eds., Oxford Handbook of Management Theorists, Oxford University Press, 2012: 361-384.

${ }^{14}$ Thomas Navin and Marion Sears, "The Rise of a Market for Industrial Securities, 1887-1902," Business History Review. 29, 2, 1955: 105-38.

${ }^{15}$ Mary O'Sullivan, “The Expansion of the U.S. Stock Market, 1885 1930: Historical Facts and Theoretical Fashions," Enterprise and Society, 8, 3, 2007: 489-542; Mary A. O'Sullivan, Dividends of Development: Securities Markets in the History of U.S. Capitalism, 1865-1922, Oxford University Press, 2016.
} 
1929 , the term "blue-chip company" came into widespread use to mean a corporation such as DuPont, General Electric, or General Motors that was one of the most profitable and best financed companies listed on the NYSE - and nevertheless companies in which shareholding bore substantial risk. With good reason, the adjective "blue chip" was taken from the color of the most valuable counter in a gambling casino. ${ }^{16}$

Then as now, public shareholders invested their money in shares that were already outstanding on the market. Unlike the owner-entrepreneurs and their private-equity partners who, as direct investors, had financed the companies from startups into going concerns by reinvesting a high proportion of the companies' profits, the new public investors did not invest in the productive capabilities of the companies that issued the shares. Once a company had gone public, it could pay shareholders dividends, but, if the growth of the firm through investments in innovation was an objective, distributions to shareholders had to leave the firm with sufficient retained earnings to invest in the productive capabilities required to generate the next round of competitive products. These corporate retentions also provided a financial foundation for long-term borrowing to leverage the funds available for investment in productive capabilities. Indeed, in the 1920s, a prime role of Wall Street in financing major U.S. corporations was to float long-term bond issues to augment the financial commitment of these companies to their innovative investment strategies. ${ }^{17}$

While the separation of ownership and control resulted in the growth of the U.S. public stock markets, it also gave birth to "managerial capitalism," which, through a corporate governance regime of retaining corporate profits and reinvesting in productive capabilities, enabled not only the growth of the firm but also the sustained industrial expansion of the U.S. economy over the larger part of the $20^{\text {th }}$ century. ${ }^{18}$ Those companies that had the financial track record to go public on the NYSE already had grown by building managerial organizations that could take over strategic control from the retiring owner-entrepreneurs. By reducing the possibility of nepotism in top-management succession, the removal of proprietary (i.e., family) control opened up new opportunities for upward mobility for career managers that helped to ensure the commitment of these managers to the long-run performance of their particular firms. ${ }^{19}$

Over the course of their careers, these salaried managers, increasing numbers of whom in the first decades of the twentieth century held university degrees in engineering or business, developed intimate knowledge of their firms' technological and organizational capabilities. With their upward mobility unimpeded by family control, a small subset of these managers rose to senior executive positions in major industrial firms. Not coincidentally, the first decades of the twentieth century also saw the dramatic transformation of the U.S. system of higher education away from the elite British model with its aristocratic pretensions to one that serviced the growing needs of U.S. industrial corporations for professional, technical, and administrative personnel. ${ }^{20}$

From the perspective of sustained industrial growth, therefore, the key impact of the separation of control from ownership in the United States was to overcome the managerial constraint on the building of organizational capabilities and the growth of the firm. Moreover, by fragmenting shareholding among a dispersed and powerless population, the separation of ownership from control

\footnotetext{
${ }^{16}$ For an early use of the term, see Cuthbert Mills, "The financial world," New York Times, June 20, 1897, p. 19.

${ }^{17}$ Vincent Carosso, Investment Banking in America, Harvard University Press, 1970.

${ }^{18}$ William Lazonick, "Controlling the Market for Corporate Control" Industrial and Corporate Change, 3, 1, 1992: 445-448. See also William Lazonick and Mary O'Sullivan, "Finance and Industrial Development, Part I: The United States and the United Kingdom" Financial History Review, 4, 1, 1997: 7-29; Mary A. O'Sullivan, Contests for Corporate Control: Corporate Governance and Economic Performance in the United States and Germany, Oxford University Press, 2000, ch. 3; O'Sullivan, "The Expansion of the Stock Market."

19 William Lazonick "Strategy, Structure, and Management Development in the United States and Britain" in Kesaji Kobayashi and Hideaki Morikawa, eds., Development of Managerial Enterprise, University of Tokyo Press, 1986: 101-146.

20 Ibid.; David F. Noble, America by Design: Science, Technology, and the Rise of Corporate Capitalism, Knopf, 1979; Louis Ferleger and William Lazonick, "Higher Education for an Innovative Economy: Land-Grant Colleges and the Managerial Revolution in America," Business and Economic History, 23, 1, 1994: 116-128.
} 
enhanced the access of these firms to committed (i.e., long-term) finance, rooted in retained earnings and supplemented by bond issues, to fund investments in organization and technology. With the separation of ownership and control supporting the social conditions of innovative enterprisestrategic control, organizational integration, and financial commitment - the managerial revolution in American business was a powerful engine of economic growth, especially in corporations that built deep technological capabilities and well-known brand names.

Even in the Great Depression of the 1930s, when, for lack of product demand, major industrial corporations laid off masses of production workers, they continued to augment their research capabilities by expanding employment of scientists and engineers. ${ }^{21}$ During World War II and the post-war decades, these investments in research capabilities enabled U.S. industrial corporations, with support from the U.S. developmental state, to make the United States the largest and most powerful economy in the world. ${ }^{22}$ Through its "retain-and-reinvest" allocation regime, the managerial corporation contributed to greater employment stability and income equity in the immediate post-World War II decades than before the 1940s and after the 1970s.

Yet the conventional wisdom was, and remains, that the separation of ownership and control occurred because of a capital constraint, not a managerial constraint, on the growth of the business enterprise. In the late nineteenth and early twentieth centuries, so the story goes, the increasing capital requirements of companies in high fixed-cost industries such as steel, oil refining, electric power, farm equipment, and automobiles outstripped the financial capacity of family proprietors and partnerships, thus necessitating raising capital on the stock market-and hence the separation of ownership and control. In The Modern Corporation and Private Property, the classic 1932 study of the separation of ownership and control, Adolf Berle and Gardiner Means made this "capital constraint" argument, and continued to do so in their later writings. For example, in his 1954 book, The $20^{\text {th }}$ Century Capitalist Revolution, Berle states that the separation of stock ownership from managerial control "was inevitable, granting that modern organizations of production and distribution must be so large as to be incapable of being owned by any individual or small group of individuals.",23

As previously indicated, the historical facts do not support this argument. The work of Alfred Chandler and other historians of the managerial revolution in American business shows that the critical constraint on the growth of major industrial enterprises was not access to finance capital but rather the availability of organizational capabilities that could develop high-quality products and access large enough shares of the product markets to transform high fixed costs into low unit costs. ${ }^{24}$ By enabling professional managers to assume positions of strategic control, the separation of control from ownership underpinned a critical social condition of innovative enterprise.

\section{The five functions of the stock market}

An understanding of the historical origins of the separation of ownership and control transforms the way in which we think about the functions of the stock market in the growth and performance of the business corporation. An analysis of the functions of the stock market is, moreover, essential for explaining the relation between value creation and value extraction in the corporate economy, including the achievement of a balance between contributions to value creation and the ability to engage in value extraction within the firm. In the United States in the post-World War II decades, a "retain-and-reinvest" regime of corporate resource allocation, under which companies retained

\footnotetext{
${ }^{21}$ David Mowery and Nathan Rosenberg, Technology and the Pursuit of Economic Growth, Cambridge University Press, 1989: chs. 2-4.

22 Matt Hopkins and William Lazonick, "Who Invests in the High-Tech Knowledge Base?" Institute for New Economic Thinking Working Group on the Political Economy of Distribution Working Paper No. 6, September 2014 (revised December 2014), at https://ineteconomics.org/ideas-papers/research-papers/who-invests-in-the-high-tech-knowledgebase.

23 Adolf A. Berle, Jr., The $20^{\text {th }}$ Century Capitalist Revolution, Harcourt, Brace and Company, 1954, p. 30; see also Gardiner

Means, "Hessen's 'Reappraisal'" Journal of Law and Economics, 26, 2, 1983, p. 298.

${ }^{24}$ See Lazonick, "Alfred Chandler's Managerial Revolution."
} 
earnings and reinvested in productive capabilities, including those of their employees, resulted in a trend toward a more equal distribution of income in the United States. In contrast, since the 1980s the tendency of major corporations to engage in "downsize-and-distribute," laying off employees, or cutting wages and benefits, and distributing corporate cash to shareholders, has resulted in a growing imbalance between value creation and value extraction, characterized by extreme concentration among the richest households and the erosion of middle-class employment opportunities. ${ }^{25}$

The preceding discussion argued that the main function of the stock market in the rise of U.S. industrial corporations to positions of dominance was "control," not "cash." The stock market enabled professional managerial employees to exercise strategic control over the allocation of corporate resources while turning the owners of the company's shares into rentiers who were neither capable of nor disposed to participating in corporate decision-making. For a company listed on the NYSE, the cash required to sustain investment in the productive capabilities of the company came from prior capital accumulations and current retentions out of profits, leveraged if necessary by bond market issues. By and large, the cash that provided this financial commitment did not come from the stock market.

But, as indicated at the outset of this paper, "control" and "cash" do not exhaust the possible functions of the stock market in the business corporation. Our research has identified three other functions that a stock-market listing can perform for a company: "creation," "compensation," and "combination."26 An understanding of the ways in which these five functions are performed, individually and interactively, is critical to an analysis of whether and to what extent the stock market is an institution that supports the processes of value creation, or whether, alternatively, it is an institution that empowers the processes of value extraction.

Here are expanded definitions of the five functions of the stock market that I listed previously that raise questions about the roles of the various functions in influencing the relation between value creation and value extraction:

- Control: A stock-market listing affects the relationship between the ownership of shares in the company and managerial control over the allocation of resources. A listing of stock on the market usually results in the separation of ownership and control. While the separation of ownership and control provides conditions for the long-term growth of the firm, it also opens up the possibility that professional managers will abuse their positions of control for their own personal benefit. The stock market also leaves open the possibility of the reintegration of ownership and control through the accumulation of shares with voting rights, either directly or through proxies. With the reintegration of ownership and control, those who exercise strategic control may have the abilities and incentives to invest in innovation. But those who gain control over corporate resource allocation may use that control to extract value for themselves, capturing the value created by past investments but eschewing investments that can create value in the future.

- Cash: The stock market can be a source of corporate finance through new share issues, at the IPO or subsequently in a secondary issue. Once a company has transformed from a new venture to a going concern, however, those who exercise strategic control must be able to limit distributions to shareholders to an amount that enables the company to retain sufficient earnings out of profits to reinvest in productive capabilities that can sustain the company as a value-creating entity. Nevertheless, the stock market remains an institution through which those who own shares can benefit from the distribution of corporate cash to shareholders in the forms of dividends and

\footnotetext{
${ }^{25}$ William Lazonick, "Labor in the Twenty-First Century."

${ }^{26}$ Marie Carpenter, William Lazonick, and Mary O'Sullivan "The Stock Market and Innovative Capability in the New Economy: The Optical Networking Industry," Industrial and Corporate Change, 12, 5, 2003: 963-1034; William Lazonick, Sustainable Prosperity in the New Economy? Business Organization and High-Tech Employment in the United States, W. E. Upjohn Institute for Employment Research, 2009; Lazonick, "The New Economy Business Model."
} 
repurchases. In the absence of appropriate regulation, the cash function of the stock market may enable value extraction that drains the company of funds needed for investment in value creation.

- Creation: By enabling private equity to exit from an investment in the productive capabilities of a company, the prospect of a stock-market listing can induce venture capital to support new firm creation and growth. But a highly speculative stock market may enable a young firm without a record of substantial profits, or even a commercial product, to do an IPO, raising the possibility that the exit of private equity may occur before the company has accumulated the productive capabilities and the financial assets to ensure its sustained growth as a value-creating entity. A highly speculative stock market may attract private equity to invest in the creation of new firms, but, as a result of speculation as well as manipulation (e.g., hyping the market), a stock-market listing may permit these shareholders to extract value even in the absence of value creation.

- Combination: A stock-market listing makes the company's shares a currency that can be used as payment, partially or wholly, for another company's shares in mergers and acquisitions (M\&A). These M\&A deals may enable the new combination to build productive capabilities that support value creation. But, with the added cash flow that an acquisition brings to the acquiring enterprise, those who control the new combination will have much greater scope for value extraction. Indeed, the objective of the acquisition may be control over cash flow for the purpose of value extraction, with the acquirer's elevated stock price enabling the acquisition.

- Compensation: A stock-market listing makes the company's shares a currency that can be issued to employees as a form of remuneration, with stock options and stock awards as prime examples. In principle, stock-based pay should motivate employees to work harder and smarter so that, through the value-creating success of the firm, they will be rewarded by higher stock prices in the future, when the options are exercised or the awards vest. Higher stock prices, driven by innovation, that reflect contributions of employees to the process of value creation may enable them to share equitably in the gains from innovation. But a stock market that is driven by speculation and manipulation, rather than innovation, may disrupt the relation between value creation and value extraction in stock-based pay, undermining the stable and equitable remuneration structures that sustained value creation generally requires.

The analysis of the five functions that the stock market performs is central to understanding whether the stock market supports the process of value creation or empowers the process of value extraction, and hence the extent to which value creation and value extraction are, or are not, in balance. ${ }^{27}$ There are two ways in which shareholders can extract value from a company via the stock market: cash dividends and stock repurchases. These two modes of value extraction are not simply alternative ways in which a shareholder can realize a yield. The difference between dividends and buybacks can be important for understanding the relation between value creation and value extraction.

Dividends accrue to shareholders for holding shares. If dividends are too high, corporate retentions out of profits may be too low to fund the investments in productive capabilities that can enable the company to grow and, possibly, deliver a new generation of innovative products. If, in the present, too much cash is extracted as dividends, the company may not have sufficient retentions to make the investments that can generate the profits out of which dividends can be paid later. That will be a problem for shareholders who, as savers rather than speculators, want to hold shares for the sake of a reliable stream of dividend income. Alternatively, the shareholder who thinks that reinvestment of earnings by the company will not generate sufficient profits in the future can take the "Wall Street walk" by selling the shares before the stock price enters into a long-term decline.

\footnotetext{
${ }^{27}$ For a statement of this problem, see William Lazonick and Mariana Mazzucato, "The Risk-Reward Nexus in the Innovation-Inequality Relationship: Who Takes the Risks? Who Gets the Rewards?" Industrial and Corporate Change, 22, 4, 2013: 1093-1128
} 
Buybacks are not the same as dividends. The only way for a shareholder to make money from stock repurchases is by selling shares; that is, by ceasing to be a shareholder and becoming a shareseller. Moreover, in selling shares, the timing of the sale determines the amount of the gains that are made. In a tender offer, shareholders are given a window of opportunity to sell the shares at a stipulated price. In open-market repurchases, which represent the vast majority of buybacks in the United States, however, the increased demand for a company's shares will lift the stock price immediately, perhaps setting off increased speculation - in some cases fomented by the manipulative activities of Wall Street traders - that raises the stock price further. In the United States, public shareholders who are simply savers are ill-positioned to take advantage of these speculative and manipulative boosts to a company's stock price because the timing of open-market repurchases is, under the Securities and Exchange Commission (SEC) Rule 10b-18, non-public information. Companies do not disclose at the time of the buyback (or even after the fact) the days on which open-market repurchases are done. Certain insiders do, however, have this information, and major Wall Street players who are in the business of timing stock purchases and sales know how to access this information and make use of it to enrich themselves.

How, then, over the course of the past century have the changing functions of the stock market in the United States affected the balance between value creation and value extraction? In the following section, I provide summaries of the evolution of the five functions on the stock market and their changing impacts on the creation-extraction relation. This discussion in turn provides the historical context for understanding how and why the ideology that a company should be run to maximize shareholder value (MSV) became full-blown and dominant during the 1980s, and how and why MSV ideology is fundamentally flawed as an approach to the governance and performance of the modern business corporation.

\section{The functions of the stock market as influences on the creation-extraction relation}

\section{a) Control: From "retain-and-reinvest" to "downsize-and-distribute"}

In the 1920s, when the NYSE emerged as a well-developed stock market, it remained largely unregulated, except by the NYSE's governing body itself. In the mid-1920s, concerned that the holders of corporate shares were being harmed by the separation of managerial control from share ownership, economist William Z. Ripley, in lectures, articles, and his book Main Street and Wall Street, decried the shareholders' lack of power and their abuse by managers who exercised control over the allocation of corporate resources. Specifically, some corporations had created "management shares"-or what today would be called dual-class shares-with disproportionate voting rights that gave their holders de jure, rather than just de facto, control over the allocation of corporate resources. Indeed, some companies were even issuing common shares with no voting rights. ${ }^{28}$ In response, the NYSE insisted that all common shares must have equal voting rights. On the surface, this change shifted power to public shareholders, but in practice, by inspiring confidence in the governance of the NYSE, the reform further fragmented shareholder power, with public shareholders remaining content to leave corporate decision-making under the control of senior executives.

When the stock-market boom of the late 1920s resulted in the Great Crash, and when, as it turned out, the Great Crash was the opening act of the descent of the U.S. economy into deep depression, the U.S. government responded with the Securities Act of 1933, regulating new share issues, and the Securities Exchange Act of 1934, regulating the trading of outstanding shares. Together, this legislation was designed to eliminate fraud and manipulation from the stock markets (as well as other financial markets). The Act of 1934 set up the Securities and Exchange Commission (SEC) to carry out this regulatory role.

Aided by the SEC's efforts to reduce fraud and manipulation on the stock market, it was the control function of the stock market that helped to keep major U.S. business corporations focused on

\footnotetext{
${ }^{28}$ William Z. Ripley, Main Street and Wall Street, Little Brown, 1927.
} 
investment in innovation and a balance between value creation and value extraction into the $1980 \mathrm{~s}$. The separation of share ownership and managerial control left professional managers in positions of strategic control. That having been said, the adherence of top executives to a retain-and-reinvest allocation regime in the postwar decades reflected the fact that their own career success within the corporation was closely bound up with the success of the business organization as a whole. Coming up through the ranks of the organization, senior executives typically accumulated a deep knowledge of the capabilities of the company and of the business sectors in which it operated, and hence had the ability to make investment decisions concerning the company's strategic direction.

Their own career experience also led them to adopt and respect the career-with-one-company norm for the "organization men" whom they led. ${ }^{29}$ In the post-World War II decades, top executives accepted the need to train, retain, and reward growing numbers of professional, technical, and administrative personnel who constituted the white-collar labor force. Given these corporate investments in human capital, it became the norm that these employees could expect to be with the company until the end of their careers, with a defined-benefit pension, based on years of service and funded by the company, in retirement. Leading companies also provided these employees with medical coverage, thus making health insurance a "private," i.e., in this case business, rather than public responsibility.

As for the blue-collar labor force, in a wide range of industries New Deal legislation compelled senior management to engage in collective bargaining over wages and benefits with mass-production unions, with seniority as a fundamental union principle for the provision of job security. ${ }^{30}$ Although bluecollar workers were known as "hourly" employees, making them potentially eligible under the Fair Labor Standards Act of 1938 for payment of "time-and-a-half" wages for hours worked overtime, the institutionalization of seniority in effect gave the blue-collar employee a career with one company that could last for decades. Some workers with substantial seniority might be laid off in a deep downturn, but they would be re-employed according to seniority in the next upturn. As long as senior executives accepted the career-with-one-company norm for a broad base of employees, they had the incentive to adhere to a retain-and-reinvest resource-allocation regime.

Retain-and-reinvest did not mean that the company should — or could - grow larger and larger in one line of business. In most industries, the innovative enterprise had to assume that over time competitors would learn how to produce an equally high-quality, or even superior, product for a market in which it had been an innovator. Those exercising strategic control would want to reallocate the company's resources-including first and foremost its human resources - to new lines of business in which developing technologies or accessing markets could make use of these capabilities. Retained earnings provided the financial foundation for exercising these strategic investments in the growth of the firm.

It was this type of strategic control that underpinned the prominence of what in his 1962 book Strategy and Structure Chandler called the "multidivisional structure." ${ }^{31}$ In her classic contribution The Theory of the Growth of the Firm, published in 1959, Edith Penrose portrayed multidivisionalization as the process through which those in positions of strategic control reallocate unused capabilities accumulated in the old lines of business to new lines of business characterized by related technologies and/or markets. ${ }^{32}$ Moving around and up a company's managerial hierarchy over the course of a career, the professional manager who attained a position of strategic control had the ability

\footnotetext{
${ }^{29}$ Lazonick, Sustainable Prosperity, ch. 3. More generally, see Hopkins and Lazonick, "Who Invests in the High-Tech Knowledge Base?"; William Lazonick, Philip Moss, Hal Salzman, and Öner Tulum "Skill Development and Sustainable Prosperity: Collective and Cumulative Careers versus Skill-Biased Technical Change," Institute for New Economic Thinking Working Group on the Political Economy of Distribution Working Paper No. 7, December 2014, at https://ineteconomics.org/ideas-papers/research-papers/skill-development-and-sustainable-prosperity-cumulative-andcollective-careers-versus-skill-biased-technical-change;

30 William Lazonick, Competitive Advantage on the Shop Floor, Harvard University Press, 1990.

${ }^{31}$ Alfred D. Chandler, Jr., Strategy and Structure: Chapters in the History of US Industrial Enterprise, MIT Press, 1962

${ }^{32}$ Edith T. Penrose, Theory of the Growth of the Firm, Blackwell, 1959; See also Edith T. Penrose, "The Growth of the FirmA Case Study of Hercules Powder Company," Business History Review, 34, 1, 1960: 1-23.
} 
to make these strategic decisions because he had developed a deep understanding of the firm's productive capabilities and the new types of products to which they could be allocated. Given the prevailing norm of a career with one company, his income and prestige generally benefited from the growth of the firm. Hence his personal incentives were aligned with the objective of making innovative use of the company's productive resources. There was a close integration of strategic decision-making with the processes of organizational learning.

There was also the potential, however, for this integration of strategy and learning to break down, undermining the value-creation process and creating conditions for predatory value extraction. ${ }^{33}$ The seeds of imbalance were sown when in the 1950s one of the oldest and strongest corporations, General Electric (GE), promulgated the ideology that "a good manager could manage any type of business." ${ }^{34}$ In the 1960s this ideology became standard fare in U.S. graduate business schools. It was used to justify the diversification of the U.S. industrial corporation into a conglomeration of different markets and locations, even if many of the different businesses into which the corporation moved had no technological or market relation to one another. GE itself diversified into a proliferation of businesses, emerging by the 1970s as an unwieldy conglomerate, with top executives in the corporate office lacking knowledge of the technological and organizational capabilities of the proliferating number of business units. Lacking this knowledge, they were reduced to "managing by the numbers," which would tend to favor cost-cutting rather than investments in innovation. ${ }^{35}$

During the 1960s what became known as the "conglomerate movement" significantly reshaped strategic control of the U.S. industrial corporation. Unlike the case of GE, most of the conglomerates were constructed by outsiders to the business corporation who, having acquired control of one company through ownership stakes, used that corporation's stock and debt to buy other companies. Run by top executives whose only interest was in acquiring more companies to build these corporate empires, the mean number of lines of business of the top 200 U.S. manufacturing corporations ranked by sales rose from 4.76 in 1950 to 10.89 in 1975 . For the 148 corporations of the 200 largest by revenues in 1950 that still existed in 1975 the mean number of lines of business rose from 5.22 to 9.74. In the conglomerate movement of the 1960s, the number of merger and acquisition (M\&A) announcements increased from an average of 1,951 per year in 1963-67 to 3,736 in 1968-72, with a peak level of 5,306 in 1969. Between 1950 and 1978 Beatrice Foods did 290 acquisitions, W. R. Grace 186, IT\&T 163, Gulf and Western 155, Textron 115, Litton Industries 99, and LTV 58. One analysis revealed that, of assets that large manufacturing and mining companies acquired when they bought other companies, the "pure conglomerate" category-that is, unrelated diversificationrepresented 10.1 percent in 1948-55, 17.7 percent in 1956-63, 34.8 percent in 1964-71, and 45.5 percent in $1972-79 .{ }^{36}$

With the downturn in the U.S. economy in the early 1970s, it became apparent that resource allocation in many U.S. industrial corporations had become over-centralized. The problem was not size per se but rather a failure of the conglomerateurs who exercised strategic control to comprehend the actual needs of the acquired businesses for investments in productive capabilities. ${ }^{37}$ In addition, particularly by the end of the 1960s, the growth of conglomerates through M\&A had been debt-financed; the debtequity ratio in U.S. manufacturing rose from 0.40 in 1960 to 0.48 in 1965 to 0.72 in 1970.

Conglomeration generally undermined the innovative capabilities of the constituent businesses, and when the 1960s stock-market bubble burst in 1970, there was mounting financial pressure on the

\footnotetext{
${ }^{33}$ The following account is drawn from William Lazonick, "Corporate Restructuring," in Stephen Ackroyd, Rose Batt, Paul Thompson, and Pamela Tolbert, eds., The Oxford Handbook of Work and Organization, Oxford University Press, 2004: 577-601, where references to the statistics cited below can be found.

${ }^{34} \mathrm{O}$ 'Sullivan, Contests for Corporate Control, ch. 4.

35 On this problem more generally at the end of the 1970s, see Robert H. Hayes and William J. Abernathy, "Managing Our Way to Economic Decline," Harvard Business Review, July-August 1980: 67-77.

36 Lazonick, "Corporate Restructuring."

37 For an excellent case study of this phenomenon, see Max Holland, When the Machine Stopped: A Cautionary Tale from Industrial America, Harvard Business School Press, 1989.
} 
corporations to shed some of the businesses that they had taken on. The conglomerate movement of the 1960s turned into the deconglomeration movement of the 1970s. The annual average of divestiture announcements had been 207 in 1963-67 (10.6 percent of M\&A announcements) but rose to 1,290 in 1968-72 (34.5 percent) and 1,266 in 1973-77 (85.9 percent). Thereafter the absolute number of average annual announced divestitures declined somewhat, to 789 (57.0 percent of M\&A announcements) in 1978-82, 1,023 (61.4 percent) in 1983-87, and 953 (74.6 percent) in 1988-92, but the undoing of the conglomerate movement continued. ${ }^{38}$

By the mid-1980s many divestitures occurred in the aftermath of hostile takeovers. Corporate raiders looked for companies that the stock market undervalued relative to the "breakup" value of their various lines of business, used debt issues to acquire the companies, and then sold off corporate divisions to pay down the debt and generate cash that they could extract. ${ }^{39}$ The "junk bond" was widely favored as a debt instrument in hostile takeovers. ${ }^{40}$ Initially, junk bonds were previouslyissued investment-grade corporate securities, the ratings of which had been lowered. Since these downgraded bonds could be bought at a deep discount, they offered a high, if risky, yield. In the first half of the 1970s Michael Milken of the Wall Street firm Drexel Burnham Lambert in effect made a market in junk bonds by convincing institutional investors, particularly mutual funds and insurance companies, to include these high-yield securities in their investment portfolios. ${ }^{41}$ Liquidity was thus bestowed on the junk-bond market, while, in a period in which escalating inflation was eroding real interest rates, institutional investors welcomed the higher risk-adjusted returns that these securities now offered.

By the late 1970s, with the junk-bond market well developed, it became possible to issue new junk bonds (as distinct from those "fallen angels" that had previously been investment grade) to finance leveraged buyouts (LBOs). Most of these LBOs were divisional buyouts in which the top managers of a business unit took it private with a view to recapturing strategic control over resource allocation. Specialized Wall Street LBO firms, of which KKR was the most prominent, would finance the LBO with the prospect of reaping returns when the newly formed private firms could do an IPO. In 1980 there were 47 divisional LBOs at an average value (in 1988 dollars) of $\$ 34.5$ million rising to a peak of 144 divisional LBOs in 1986 at a real average value of $\$ 180.7$ million.

In 1987 and 1988, however, whole company LBOs became more prevalent; there were 47 in 1987 and 125 in 1988 at an average value in 1988 dollars of $\$ 480$ million, with the most famous one being the KKR buyout of RJR Nabisco for $\$ 24.5$ billion. ${ }^{42}$ The purpose of these LBOs-also known as hostile takeovers-was usually to take over companies in order to sell off the pieces, while also extracting value by downsizing the labor force and ramping up distributions to shareholders in the forms of dividends and buybacks. By the last half of the 1980s, the era of "downsize-and-distribute" had clearly arrived. ${ }^{43}$

\section{b) Cash: Finance for value creation or booty for value extraction?}

The use of the stock market to buy and sell companies in the conglomerate movement of the 1960s undermined the integration of strategic control with the processes of organizational learning, and opened the door for financial interests who had played little if any role in contributing to value

\footnotetext{
38 Lazonick, "Corporate Restructuring,"

39 William F. Long and David J. Ravenscraft, "Decade of Debt: Lessons from LBOs in the 1980s," in Margaret Blair, ed., The Deal Decade, Brookings Institution, 1993.

40 Robert A. Taggart, Jr., "The Growth of the 'Junk' Bond Market and its Role in Financing Takeovers," in Alan Auerbach, ed., Mergers and Acquisitions, University of Chicago Press, 1988.

${ }^{41}$ Connie Bruck, The Predators' Ball, Penguin. 1989.

42 Michael C. Jensen, "Eclipse of the Public Corporation," Harvard Business Review September-October 1989: 61-74; Patrick A. Gaughan, Mergers, Acquisitions, and Corporate Restructurings, 2nd edition, John Wiley and Sons, 1996.

43 See Lazonick, "Labor in the Twenty-First Century"; William Lazonick and Jang-Sup Shin, "Rebalancing Value Creation and Value Extraction: How to Deactivate Hedge Funds and Restore Sustainable Prosperity," Report to the Korea Economic Research Institute, May 2017.
} 
creation to attain positions of strategic control. Increasingly, they used this power to drain cash from companies in the forms of executive pay, management fees, interest rates, cash dividends, and stock buybacks. From the mid-1980s, as we have seen, buybacks emerged, on top of dividends, as a leading mode of value extraction, incentivized from within the corporate suite by stock-based executive pay. In the process, the stock market began to perform a negative cash function that has increased from decade to decade. ${ }^{44}$

The stock market plays a positive cash function when a company issues shares at its IPO or in a subsequent (often called secondary) stock offering. The funds that are raised may be used for investment in productive capabilities. Or the funds may be retained to solidify the corporate balance sheet, possibly providing the capitalization that permits a company to take on debt with little risk of being forced into bankruptcy if business temporarily goes bad. In the Old Economy corporation, fundraising in the IPO was relatively unimportant to corporate finance because, given the NYSE listing requirements, companies that went public on the NYSE already had accumulated cash reserves and a level of profits that could fund internal investments on an ongoing basis. If a company needed to leverage these retentions, its NYSE listing gave it access to the corporate bond market at favorable rates. Once listed on the stock market, these companies sought to pay stable dividends in order to meet the income expectations of their "loyal" shareholders. Until companies started to do large-scale stock buybacks in 1984, profits retained after the payment of dividends formed a firm foundation of financial commitment.

In general, therefore, NYSE companies did not do secondary stock offerings-with one notable period in which the exception proved the rule. In the late 1920, with salaried executives in control of major corporations, many publicly-listed companies did large-scale share issues on the NYSE, even as they were channeling large sums of surplus cash to speculators who were buying corporate shares on margin with funds borrowed on the call-loan market at 10 to 15 percent interest rates. The purpose of these corporate share issues, however, was not to raise funds for new investment in productive capabilities but rather to take advantage of high stock-prices driven by stock-market speculators to use the influx of cash to pay off debt or bolster the corporate treasury. ${ }^{45}$ This type of financial engineering would stand these companies in good stead at the beginning of the 1930s after the economy had moved from boom to bust.

In historical retrospect, this financial behavior also contrasts dramatically with the practice of major U.S. corporations over the past two decades of doing large-scale stock repurchases when the stock market is booming for the purpose of pushing up their stock prices further. ${ }^{46}$ In the current era, as we have seen, senior executives have done large-scale stock buybacks in booming stock markets for the benefit of their pay packages, laden as they are with the gains from exercising stock options and the vesting of stock awards. In the late 1920s, however, with the managerial revolution intact, senior executives sold corporate shares on the speculative market to improve the financial condition of the companies over which they exercised strategic control, not for the sake of increasing their own compensation. The growing importance over the past three decades of stock buybacks, which have been especially large and widespread during boom periods, when stock prices are high, manifests a dramatic transformation of U.S. corporations from retain-and-reinvest to downsize-and-distributeand hence from a balance to an imbalance of the relation between value creation and value extraction.

\section{c) Creation: The role of the stock market in new-firm formation}

The 1971 launch of the National Association of Security Dealers Automated Quotation electronic exchange, better known as NASDAQ, created a highly liquid stock market with much less stringent

\footnotetext{
44 William Lazonick, "Profits Without Prosperity: Stock Buybacks Manipulate the Market and Leave Most Americans Worse Off," Harvard Business Review, September 2014, 46-55; Lazonick, "Stock Buybacks"; Lazonick, "The Value-Extracting CEO."

45 Gene Smiley and Richard H. Keehn, "Margin Purchases, Brokers' Loans and the Bull Market of the Twenties," Business and Economic History. $2 \mathrm{~d}$ series. 17, 1988: 129-142.

46 Lazonick, "Profits Without Prosperity"; Lazonick, "Stock Buybacks."
} 
listing requirements than the NYSE. By making it much easier for a young company to do an IPO a few years after its founding, the existence of NASDAQ induced private equity to flow to startups. The first company to list on NASDAQ was Intel, founded in 1968 and publicly listed in 1971. When Intel sought startup funding, without NASDAQ in place, the money was secured because of the reputation of its founders Gordon Moore and Robert Noyce and their connection with a pioneer venture capitalist Arthur Rock. But with NASDAQ in operation, a specialized industry dedicated to new-firm creation in high-tech fields rapidly emerged in the 1970s, especially in the region south of San Francisco, centered on Stanford University. It was also in 1971, the same year as NASDAQ's inauguration, that a local journalist dubbed this industrial district "Silicon Valley."

In 1975, the SEC barred stock exchanges from charging fixed commissions on stock-trading transactions, ending a practice that had prevailed on Wall Street since 1796. This change made it less costly for stock-market traders to buy and sell shares to realize capital gains as an alternative to holding the shares for the sake of a stream of dividend income, and thus facilitated early IPOs of new ventures that were not yet profitable enough to pay dividends. It also favored the subsequent growth of the firm as a publicly-listed company because of the willingness of capital-gains oriented stockmarket traders to forego dividends, thus leaving more earnings in the company for internal investment.

In 1978-1979, in response to intensive lobbying led by the American Electronics Association and the National Venture Capital Association (both of which were dominated by Silicon Valley interests), the U.S. Congress reduced the capital-gains tax rate from a maximum of almost 40 percent to a maximum of 28 percent, thus reversing a 36-year trend toward higher capital-gains taxes. ${ }^{48}$ In 1981 the capitalgains tax rate was further reduced to a maximum of 20 percent. Venture capitalists saw lower capitalgains taxes as encouraging both entrepreneurial investment in new companies and portfolio investment by individuals in the publicly traded stocks of young, potentially high-growth firms.

During the 1970s, however, venture capitalists still faced constraints on the amount of money that they could raise for venture funds, mainly because of restrictions on their access to the vast accumulation of household savings held by pension funds. In the early 1970s there was only a trickle of institutional money invested in venture capital, and even that flow dried up when the passage of the Employee Retirement Income Security Act (ERISA) in 1974 made corporations responsible for underfunded pensions and pension-fund managers personally liable for breaches of their fiduciary duty to use the "prudent man" rule when allocating pension funds to investments in securities. Under these circumstances, pension-fund managers, who controlled the allocation of an ever-increasing share of U.S. household savings, avoided investment in venture-capital funds.

On July 23, 1979, however, the U.S. Department of Labor decreed that, under ERISA, pension-fund money could be invested not only in listed stocks and high-grade bonds but also in more speculative assets, including new ventures, without transgressing the prudent man rule. As a result, pension-fund money poured into venture-capital funds. Independent venture partnerships (the type that prevailed in Silicon Valley) increased their access to the capital of pension funds from, measured in 1997 dollars, $\$ 69$ million in 1978, just 15 percent of all funds raised, to $\$ 1,808$ million in 1983 . Throughout the 1980s and 1990s, pension funds provided anywhere from 31 percent to 59 percent of the funds raised by independent venture-capital partnerships, which in turn increased their share of all venture funds raised from 40 percent in 1980 to 80 percent a decade later. ${ }^{49}$

Apple Computer's highly successful IPO in December 1980 is generally credited with setting off the startup and IPO booms of the early 1980s. After achieving spectacular returns on its investments, averaging about 35 percent, between 1978 and 1983, the venture-capital industry was punished for over-investing, with returns averaging less than 10 percent in the last half of the 1980s. After 1990

\footnotetext{
47 Lazonick, Sustainable Prosperity, ch. 2; Lazonick, "The New Economy Business Model."

48 Lazonick, Sustainable Prosperity, ch. 2.

49 Paul Gompers and Josh Lerner, The Venture Capital Cycle, MIT Press, 2002, p. 8.
} 
returns moved up once again, soaring to almost 150 percent at the peak of the Internet boom before turning negative in the crash of 2001 and $2002 .^{50}$

The Silicon Valley venture-capital model spread to other parts of the United States, especially during the 1990s, with investments being made in many different locations and a wide range of industries. Measured in 2000 dollars, total venture-capital investment in the United States rose from $\$ 9.1$ billion in 1995 to $\$ 22.3$ billion in 1998 before skyrocketing to $\$ 55.9$ billion in 1999 and $\$ 105.0$ billion in 2000. After falling to $\$ 39.5$ billion in 2001, venture-capital investment averaged $\$ 21.4$ billion per year from 2002 to 2007, including $\$ 25.3$ billion in 2007. In current dollars, venture-capital investment declined from $\$ 30.5$ billion in 2007 to $\$ 28.3$ billion in $2008 .{ }^{51}$ After a sharp slump in venture financing in 2009 and 2010, the industry recovered reaching $\$ 73.3$ billion in 2015 and $\$ 59.0$ billion in 2016. Silicon Valley remains by far the world's most important location for venture capital. ${ }^{52}$

The centrality of a rapid stock-market listing to the creation function under the New Economy business model meant that from a very early stage in the growth of the firm, those who exercised strategic control in these New Economy companies had a deep concern with their company's stock price. Indeed, in a speculative stock market, the IPO itself created opportunities for value extraction without value creation. In the dot.com boom of the late 1990s, companies with no commercial products could do an IPO for billions of dollars, netting fortunes for senior executive and venture capitalists even if the company would eventually fail. ${ }^{53}$ In the biopharma industry, in which it can take billions of dollars and a decade or two to develop an effective new drug, product-less IPOs on NASDAQ are the rule in the United States. Through the National Institutes of Health, the taxpayer funds scientific discovery and even in many cases clinical trials, while countless scientists in government and university research labs contribute to the drug-development process. Yet it is financial interests who reap the lion's shares of the gains by selling shares on the speculative, and often manipulated, stock market. In the world of product-less IPOs, those who contribute most to the collective and cumulative process of value creation often share least in the process of value extraction. And by funneling financial resources into the hands of the value extractors, the very process of value extraction often cuts short or dooms to failure the process of value creation. ${ }^{54}$

\section{d) Combination: Stock as a currency for M\&A}

Since the Great Merger Movement of the 1890s and early 1900s, there have been a number of waves of merger and acquisition (M\&A) activity in the United States, most notably in the mid-1920s, 1960s, 1980s, and 1990s. An M\&A deal can be carried out with cash or with stock or with some combination of the two. While stock has often been used as a currency to fund combinations, it was in the 1990s that its use became most pronounced. ${ }^{55}$

In their Harvard Business Review article, entitled "Stock or Cash?", published in 1999 at the peak of the Internet boom, Alfred Rappaport and Mark Sirower argued:

\footnotetext{
${ }^{50}$ Paul Gompers and Josh Lerner, "Short-Term America Revisited: Boom and Bust in the Venture Capital Industry and the Impact on Innovation," in Adam B. Jaffe, Josh Lerner, and Scott Stern, eds., Innovation Policy and the Economy, Volume 3, National Bureau of Economic Research, 2003: 1-27, at http://www.nber.org/chapters/c10791.

${ }^{51}$ PricewaterhouseCoopers, 2008, "MoneyTree Report," at https://www.pwcmoneytree.com/MTPublic/ns/index.jsp.

52 PWC and CB Insights, 2016 Venture Capital Funding Report, at https://www.cbinsights.com/research-venture-capitalreports-q4-2016.

53 John Cassidy, Dot.Con: How America Lost Its Money and Its Mind in the Internet Era, Harper Perennial, 2003; Gimein, Mark, Eric Dash, Lisa Munoz, and Jessica Sung. 2002. "You bought. They sold." Fortune, September 2, 2002, at http://archive.fortune.com/magazines/fortune/fortune_archive/2002/09/02/327903/index.htm; Lazonick, "The ValueExtracting CEO."

${ }^{54}$ William Lazonick and Öner Tulum, "US Biopharmaceutical Finance and the Sustainability of the Biotech Business Model," Research Policy, 40, 9, 2011: 1170-1187; William Lazonick, Matt Hopkins, Ken Jacobson, Mustafa Erdem Sakinç, and Öner Tulum, "U.S. Pharma's Business Model: Why It Is Broken, and How It Can Be Fixed," in David Tyfield, Rebecca Lave, Samuel Randalls, and Charles Thorpe, eds., The Routledge Handbook of the Political Economy of Science, Routledge, 2017: 83-100.

${ }^{55}$ Carpenter, et al, "The Stock Market and Innovative Capability"; Lazonick, "Corporate Restructuring"
} 
The legendary merger mania of the 1980s pales beside the M\&A activity of this decade. In 1998 alone, 12,356 deals involving U.S. targets were announced for a total value of \$ 1.63 trillion. Compare that with the 4,066 deals worth $\$ 378.9$ billion announced in 1988 , at the height of the 1980s merger movement. But the numbers should be no surprise. After all, acquisitions remain the quickest route companies have to new markets and to new capabilities. As markets globalize, and the pace at which technologies change continues to accelerate, more and more companies are finding mergers and acquisitions to be a compelling strategy for growth. What is striking about acquisitions in the 1990s, however, is the way they're being paid for. In 1988, nearly $60 \%$ of the value of large deals - those over $\$ 100$ million-was paid for entirely in cash. Less than $2 \%$ was paid for in stock. But just ten years later, the profile is almost reversed: $50 \%$ of the value of all large deals in 1998 was paid for entirely in stock, and only $17 \%$ was paid for entirely in cash. ${ }^{56}$

An advantage of using stock as a combination currency was that accounting rules in place in the United States in the 1990s enabled a company to treat an acquisition as a "pooling of interests"; the enlarged entity accounted for its additional assets at the book value of the acquired company, and thus avoided recording goodwill - the difference between the market value and the book value of the acquisition - as an intangible asset on its balance sheet. By not having to amortize goodwill, the enlarged company would show higher earnings on its profit-and-loss statement over subsequent years than if it had recorded the acquisition at its purchase price. During the conglomerate boom of the 1960s, many pooling-of-interests acquisitions were made with debt or with a combination of securities and cash. ${ }^{57}$ In 1970, in response to abuses of pooling-of-interests accounting during the conglomerate era, the Accounting Principles Board (replaced in 1973 by the Financial Accounting Standards Board [FASB]), ruled, among other things, that only acquisitions made entirely with common stock could use pooling of interests accounting. ${ }^{58}$

The New Economy boom of the 1990s raised the value of shares relative to cash, thus making stock a relatively more attractive combination currency. Pooling-of-interests accounting made stock-based acquisitions especially advantageous to reported earnings when established companies were bidding for relatively young companies - indeed in some cases revenue-less startups-with low book values. It may well be for these reasons that the use of stock instead of cash as an acquisition currency was much more prevalent in the United States in the late 1990s than it had been during the late 1980 s. $^{59}$ The collapse of stock prices that occurred in late 2000 and the first half of 2001 led to widespread criticism of pooling of interests, and in July 2001 the FASB banned the further use of this method of accounting for acquisitions.

An exemplar in using stock as a combination currency in the 1990s was Cisco Systems. Founded in 1984 in the heart of Silicon Valley, Cisco grew from \$70 million in sales and 254 employees in 1990, the year of its IPO, to $\$ 18.9$ billion in sales and 34,000 employees a decade later. By that time, Cisco had dominated the market for networking equipment, and was entering the more complex market for service-provider (or carrier-class) communication technology.

Key to Cisco's growth from 1993 were numerous acquisitions of other technology companies. From 1993 through 2000, Cisco did 60 acquisitions, valued at $\$ 32.5$ billion of which 98 percent was paid in Cisco's shares. ${ }^{60}$ Through this "growth-through-acquisition" strategy, by the late 1990s Cisco could

\footnotetext{
56 Alfred Rappaport and Mark L. Sirower. "Stock or Cash: The Trade-Off for Buyers and Sellers in Mergers and Acquisitions," Harvard Business Review, November-December, 1999: 147-158.

57 The Editors of Fortune, The Conglomeration Commotion, Viking, 1970; John Brooks, The Go-Go Years: The Drama and Crashing Finale of Wall Street's Bullish 60s, Dutton, 1973, pp. 160-61.

58 Frank R. Rayburn and Ollie S. Powers, "The History of Pooling of Interests Accounting for Business Combinations in the United States," Accounting Historians Journal, 18, 2, 1991: 155-192; Joel Seligman, The Transformation of Wall Street, $3^{\text {rd }}$ edition, Aspen Publishers, 2003, pp. 419-431.

59 Rappaport and Sirower, "Stock or Cash?".

${ }^{60}$ Carpenter et al., "The Stock Market and Innovative Capability."
} 
claim to have been the fastest growing company in U.S. history. ${ }^{61}$ Meanwhile, in the Internet boom, two of Cisco's Old Economy competitors, U.S.-based Lucent, the largest communication-technology company in the world in 2000, and Nortel, based in Canada but with its largest footprint in the United States, destroyed themselves by emulating Cisco's growth-through-acquisition model, doing acquisitions, using massive amounts of stock as the acquisition currency. The hype surrounding these acquisitions gave their stock prices a boost in the Internet boom but left them with massive losses and junk-bond ratings in the bust. ${ }^{62}$

Given the centrality of its equipment to the growth of the Internet economy, Cisco would have shown substantial profits in the last half of the 1990s under any circumstances. But its use of pooling-ofinterests accounting helped increase its reported profits even more, adding to the speculative fervor over its stock. In March 2000, Cisco had the highest market capitalization in the world. A Barron's editor calculated that to justify Cisco's stock price of 130 times estimated earnings per share for 2000, Cisco's earnings, which stood at $\$ 2.5$ billion in 1999 , would have to reach $\$ 2.5$ trillion in 2010! ${ }^{63}$

With the bursting of the Internet bubble, in September 2001, Cisco's stock price fell to just 15 percent of its March 2000 peak. At that point, Cisco began doing stock buybacks to boost its stock price. Its buybacks escalated from $\$ 1.9$ billion in fiscal 2002 (ending July 27, 2002), $\$ 5.9$ billion in 2003, $\$ 9.1$ billion in 2003, and $\$ 10.2$ billion in 2004. In all, from 2002 through 2016 Cisco did $\$ 97.5$ billion in buybacks, equal to 95 percent of its net income, to which it added (from 2011 through 2016) \$18.1 billion in dividends. By 2004 Cisco was doing its acquisitions in cash, and in the case of its largest acquisition, Scientific Atlanta for $\$ 6.9$ billion done in 2005 , it took on debt, largely because in doing buybacks to boost its stock price it did not want to dilute its shareholding using its stock as an acquisition currency.

Our detailed research on Cisco reveals that as it dramatically ramped up its spending on stock buybacks in the first half of the 2000s it eschewed making deep investments in carrier-class communication equipment, a segment that, as a result of acquisitions made in the previous boom, it was positioned to enter. Instead, most of Cisco's acquisitions during the 2000s brought the company products that turned out to be commodities. Given its dominant position in enterprise communication equipment, the growth of data centers and cloud computing enabled Cisco from 2004 to 2016 to increase its sales from $\$ 22$ billion to over $\$ 49$ billion and its employees from 34,000 to 74,000. But, with an obsessive focus on manipulating its stock price, Cisco ceased to be an innovative enterprise. ${ }^{64}$ Today, the world leader in communication technology - the company that, in my view, Cisco could have been-with large market shares in service-provider equipment, enterprise equipment, and consumer handsets, is the Chinese company Huawei, founded in 1987 in the then unsophisticated city of Shenzhen, three years after Silicon Valley's Cisco emerged out Stanford University. Through a retain-and-reinvest allocation regime, by 2016 Huawei had $\$ 78$ billion in revenues and 180,000 employees. Huawei does not do stock buybacks because, as a $100 \%$ employee-owned company, it is not listed on a stock market. ${ }^{65}$

\footnotetext{
${ }^{61}$ Charles O'Reilly, "Cisco Systems: the Acquisition of Technology is the Acquisition of People", Graduate School of Business, Stanford University Case Study, October 1998.

${ }^{62}$ Carpenter et al., "The Stock Market and Innovative Capability"; William Lazonick and Edward March, "The Rise and Demise of Lucent Technologies," Journal of Strategic Management Education, 7, 4, 2011.

${ }^{63}$ Thomas Donlan, "Cisco bids," Barron's, May 8, 2000: 31-34.

${ }^{64}$ Bob Bell, Marie Carpenter, Henrik Glimstedt, and William Lazonick, “Cisco's Evolving Business Model: Do Stock Buybacks Affect Corporate Performance?" The Academic-Industry Research Network Working paper, November 2014; see also Marie Carpenter, and William Lazonick, "Innovation, Competition, and Financialization in the Communications Technology Industry, 1996-2016", paper prepared for the European Commission Horizon Project on Innovation-Fuelled Sustainable and Inclusive Growth, May 2017, at http://www.isigrowth.eu/2017/06/14/innovation-competition-andfinancialization-in-the-communications-technology-industry-1996-2016/

65 Huawei Investment \& Holding Co., Ltd., 2016 Annual Report, at http://www-file.huawei.com//media/CORPORATE/PDF/annual-report/AnnualReport2016_en.pdf?la=en-US
} 


\section{e) Compensation: Stock as a currency for employee pay}

The stock market can perform a compensation function by enabling a company to use its shares to pay a substantial portion of the remuneration of employees, among whom the greatest beneficiaries are senior executives who exercise strategic control over the allocation of corporate resources ${ }^{66}$ In the 1950s, stock-based compensation became a source of additional income for senior executives of major U.S. companies. With personal income in excess of $\$ 200,000$ taxed at a rate of 91 percent, the Revenue Act of 1950 gave senior executives the right to pay the capital-gains tax of 25 percent on the gains from exercising "qualified" stock options, provided that the acquired stock was held for at least two years from the grant date and six months from the exercise date. From the late 1950s, there was a public backlash against this tax privilege of executives, leading the U.S. Congress to pass legislation that made it more difficult for executives to make use of this capital-gains loophole, and the Tax Reform Act of 1976 closed it completely. In 1978 Graef Crystal, an executive compensation consultant who would later become a vocal critic of excessive executive pay, stated that qualified stock options, "once the most popular of all executive compensation devices, ... have been given the last rites by Congress."

From the beginning of the 1980s, however, executive stock options, with the gains now taxed at the ordinary income-tax rate-which declined dramatically with the coming of Reaganomics-reemerged with a vengeance. The driving force for the re-emergence of stock options as a form of compensation was the rapid growth of the New Economy business model in the 1980s, as startup companies sought to use stock options to lure away professional, technical, and administrative personnel from career-long employment security at Old Economy companies. As startups, the New Economy companies could not hold out the Old Economy promise of a career with one company with a defined-benefit pension in retirement. As New Economy companies such as Oracle, Microsoft, and Cisco grew to employ tens of thousands of people in the 1990s, they continued to use stock options as partial remuneration for most of them. By the 2000s, the career-with-one-company norm was largely gone, exposing even college-educated workers to high levels of employment insecurity and often truncated careers if and when the senior executives for whom they worked decided to transform from retain-and-reinvest to downsize-and-distribute.

Broad-based stock options proved to be problematic modes of employee remuneration in the New Economy companies as well. In the Internet boom of 1996-2000 at certain high-tech companies the gains from exercising stock options were so high that they fostered the hypermobility of labor that undermined the commitment of these employees to engage in the collective and cumulative learning processes that are central to innovation. For example, at Microsoft, the average gains per employee (excluding the CEO and other four highest paid) from exercising stock options were $\$ 79,000$ across 19,200 employees in 1996 before soaring to $\$ 369,700$ across 29,2000 employees in 1999 and a peak of $\$ 449,100$ across 35,200 employees in 2000 before falling back to $\$ 80,300$ across 52,800 employees in 2003. It is said that there were 10,000 Microsoft millionaires created in 2000 alone, large numbers of whom became angel investors, founded or joined startups, or retired at an early age. This hypermobility of labor disrupted projects at Microsoft Research, which had been launched in 1991, and helped to ensure that the company would not be a leader in innovation in the $2000 \mathrm{~s}$ and beyond. ${ }^{68}$

During the 1980s and 1990s, as broad-based stock option programs became a widespread mode of remunerating rank-and-file high-tech employees, senior executives of these companies received stock options in abundance on the basis of special top-executive compensation packages meted out by their boards. As top executives of New Economy companies found themselves receiving unprecedented levels of stock-based remuneration, the senior executives of Old Economy companies clamored for

\footnotetext{
${ }^{66}$ Matt Hopkins and William Lazonick, "The Mismeasure of Mammon: Uses and Abuses of Executive Pay Data," Institute for New Economic Thinking Working Paper No. 49, August 29, 2016, at https://www.ineteconomics.org/ideaspapers/research-papers/the-mismeasure-of-mammon-uses-and-abuses-of-executive-pay-data

67 Graef Crystal, Executive Compensation: Money, Motivation, and Imagination, American Management Association, 1978, p. 145; Graef S. Crystal, In Search of Excess: The Overcompensation of the American Executive, Norton, 1991.

${ }^{68}$ Lazonick, Sustainable Prosperity.
} 
this mode of compensation as well. In the process, a distinctive procedure emerged for rewarding top executives which has had a "ratchet effect" in pumping up executive pay over time, severing any plausible relation between the executives' contributions to value creation through their strategic decision-making and their value extraction through remuneration. Indeed, in the United States executive stock-based pay incentivizes those who exercise strategic control to adopt a downsize-anddistribute resource-allocation regime. ${ }^{69}$

The result has been an ongoing explosion of executive pay since the 1980s. The average total compensation of the 500 highest-paid executives in the ExecuComp database for each year from 2006 through 2015 ranged from a low of $\$ 15.9$ million in 2009, when the stock markets had crashed, with stock-based pay (realized gains from stock options and stock awards) making up 60 percent of the total, to a high of $\$ 32.6$ million in 2015 , with stock-based gains making up 82 percent of the total. U.S. corporate executives are incentivized to boost their companies' stock prices and are amply rewarded for doing so. In SEC-approved stock buybacks, they have at their disposal an instrument to enrich themselves. In their massive, widespread, and ubiquitous use of this instrument, they have been participating in the looting of the U.S. business corporation. ${ }^{70}$

\section{Maximizing shareholder value as an ideology of value extraction}

Legitimizing the looting of the U.S. industrial corporation has been the ideology that a company should be run to "maximize shareholder value" (MSV). From this perspective, the main problem of large corporations is the alleged tendency of managers, in control of the allocation of vast corporate resources, to "build empires" by investing in wasteful projects for their personal aggrandizement. The proponents of MSV argue that hostile takeovers, more generally known as "the market for corporate control," can force managers to stop dissipating corporate resources and distribute cash to shareholders. The MSV proponents also argue that by making stock-based pay a major proportion of executive compensation, the incentives of corporate managers in the allocation of resources can be aligned with those of public shareholders. ${ }^{71}$ Only by "disgorging" the corporation's "free cash flow" to shareholders in the forms of cash dividends and stock repurchases, they contend, can the economy's resources be allocated to their most efficient uses. ${ }^{72}$

MSV ideology is rooted in two misconceptions of the role of public shareholders in the U.S. business corporation. The most fundamental error is the assumption that public shareholders invest in the productive assets of the corporation. That error is then compounded by the assumption that it is only public shareholders who make risky investments in the corporation's productive assets, and hence that it is only shareholders who have a claim on the corporation's profits. Once we recognize the flaws in these assumptions, the factual foundation for MSV ideology falls apart.

Central to the MSV argument is the assumption that, of all participants in the business corporation, shareholders are the only economic actors who make productive contributions without a guaranteed return. All other participants such as creditors, workers, suppliers, and distributors allegedly receive a market-determined price for the goods or services that they render to the corporation, and hence take no risk of whether the company makes or loses money. On this assumption, the very definition of "free cash flow" includes corporate earnings that under a retain-and-reinvest resource-allocation regime the corporation would have invested in training, retaining, and rewarding employees. And on this assumption, only shareholders have an economically justifiable claim to the "residual" of revenues over costs after the company has paid all other stakeholders their guaranteed contractual claims for their productive contributions to the firm.

\footnotetext{
${ }^{69}$ Lazonick, "The Value-Extracting CEO."

70 Hopkins and Lazonick, "The Mismeasure of Mammon"; Lazonick, "The Value-Extracting CEO."

${ }^{71}$ Michael C. Jensen and Kevin Murphy, "Performance Pay and Top Management Incentives," Journal of Political Economy, 98, 2, 1990: 225-264.

72 Jensen, "Agency Costs of Free Cash Flow."
} 
By the MSV argument, shareholders are the only stakeholders who need to be incentivized to bear the risk of investing in productive resources that may result in superior economic performance. As the only "residual claimants," the MSV story goes, shareholders are the only stakeholders who have an interest in monitoring managers to ensure that they allocate resources efficiently. Furthermore, by buying and selling corporate shares on the stock market, public shareholders, it is argued, can directly reallocate resources to uses that are more efficient than investments within the corporation.

As already stated, there are two fundamental flaws with this argument. ${ }^{73}$ The first flaw is the contention that, via the stock market, public shareholders allocate resources to more efficient uses. As a general rule, they do not. Passive shareholders provide their savings to the stock market to seek yields on their savings. But these funds simply increase the demand for already outstanding shares of companies that, through the value-creation process-combining strategic control, organizational integration, and financial commitment-have already determined the most "efficient" uses of productive resources, typically making little if any use of the stock market as a source of financial commitment. In contrast, in the name of MSV, active public shareholders seek to extract value from companies that, without these shareholders' participation in the value-creation process, have been successful in generating high-quality, low-cost products. Most representative today of active shareholders are hedge-fund activists, formerly known as corporate raiders and better described as corporate predators, who seek to extract value from companies by pressuring CEOs and their boards to downsize and distribute, and where possible engage in price gouging of buyers, so that they can sell their shares at higher prices and thereby build their hedge-fund "war chests," thus increasing their financial power to extract even more value from companies as time goes on ${ }^{74} \mathrm{MSV}$ is the ideology that legitimizes this looting of the industrial corporation.

The second flaw with MSV lies in the erroneous assumption that shareholders are the only corporate participants who bear risk. Taxpayers through government agencies and workers through the firms that employ them make risky investments in productive capabilities on a regular basis. From this perspective, households as taxpayers and workers may have "residual claimant" status: that is, an economic claim on the distribution of profits.

Through government investments and subsidies, taxpayers regularly provide productive resources to companies without a guaranteed return. As an important example, but only one of many, the 2016 budget of the U.S. National Institutes of Health (NIH) is \$32.3 billion, with a total NIH investment in life-sciences research from 1938 through 2016 of just under $\$ 1$ trillion in 2016 dollars. ${ }^{75}$ Businesses that make use of life-sciences research benefit from the public knowledge that the NIH generates. As risk bearers, taxpayers who fund such investments in the knowledge base, or physical infrastructure such as roads, have a claim on corporate profits if and when they are generated. Through the tax system, governments, representing households as taxpayers, seek to extract this return from corporations that reap the rewards of government spending. However, tax revenues on the prospective gains from innovation depend on the success of innovative enterprise while, through the political process, tax rates on those gains are subject to change. Hence, for both economic and political reasons, the returns to taxpayers whose money has been invested for the benefit of business enterprises are by no means guaranteed.

\footnotetext{
${ }^{73}$ See William Lazonick and Mary O'Sullivan, "Maximizing Shareholder Value: A New Ideology for Corporate Governance," Economy and Society, 29, 1, 2000: 13-35; Lazonick, "Innovative Enterprise and Shareholder Value"; Lazonick, "Stock Buybacks."

${ }^{74}$ As an example, see William Lazonick, Matt Hopkins, and Ken Jacobson, "What we learn about inequality from Carl Icahn's \$2 billion 'no brainer'," Institute For New Economic Thinking Perspectives, June 6, 2106, at https://www.ineteconomics.org/perspectives/blog/what-we-learn-about-inequality-from-carl-icahns-2-billion-apple-nobrainer; See also Lazonick, et al., "U.S. Pharma's Business Model.” These arguments are elaborated in Lazonick and Shin, "Rebalancing Value Creation and Value Extraction." See also Lazonick and Mazzucato, "The Risk-Reward Nexus."

75 National Institutes of Health, "Budget," at http://www.nih.gov/about-nih/what-we-do/budget. See also Lazonick and Tulum, "US Biopharmaceutical Finance."
} 
Workers regularly make productive contributions to the companies for which they work through the exercise of skill and effort beyond those levels required to lay claim to their current pay, but without guaranteed returns. ${ }^{76}$ Any employer who is seeking to generate a higher-quality, lower-cost product knows the profound productivity difference between employees who just punch the clock to get their daily pay and those who engage in learning to make productive contributions through which they can build their careers and thereby reap future returns in work and in retirement. Yet these careers and the returns that they can generate are not guaranteed, and under the downsize-and-distribute resourceallocation regime that MSV ideology has helped put in place these returns and careers have been, in fact, undermined.

As risk bearers, therefore, taxpayers whose money supports business enterprises and workers whose efforts generate productivity improvements have claims on corporate profits if and when they occur. MSV ignores the risk-reward relation for these two types of economic actors in the operation and performance of business corporations. Instead it erroneously assumes that shareholders are the only residual claimants.

The irony of MSV is that the public shareholders whom it holds up as the only risk bearers typically never invest in the value-creating capabilities of the company at all. Rather, they purchase outstanding corporate equities with the expectation that while they are holding the shares dividend income will be forthcoming and with the hope that when they decide to sell the shares the stock-market price will have risen to yield a capital gain. Following the directives of MSV, a prime way in which the executives who control corporate resource allocation fuel this hope is by allocating corporate cash to stock buybacks to pump up their company's stock price. Yet it is the senior executives themselves who are best positioned to gain from these manipulative price increases. Senior executives "disgorge" this cash flow, not for the sake of efficient resource allocation, but rather for the sake of increasing their own stock-based pay. ${ }^{77}$ On an increasing scale since the early 2000 s, corporate predators now known as "hedge-fund activists" have joined with senior executives and their boards in accelerating this looting of the U.S. business corporation. ${ }^{78}$

In the process, the triumph of MSV has been eroding the social conditions of innovative enterprise: strategic control, organizational integration, and financial commitment. I conclude this essay with brief statements of how, legitimized by MSV, the current operation of U.S. stock markets as valueextracting institutions have been undermining innovative enterprise.

\section{Strategic control}

Senior executives who are willing to waste hundreds of millions or billions of dollars annually on buybacks in order to manipulate their companies' stock prices are likely to lose the judgmental capacity to comprehend the types of investments in organization and technology that are required to remain innovative in their industries. Executives' use of financial tools to determine whether the "relevant cost of capital"(as Jensen put it in an essay on "agency costs" ${ }^{\text {"79) }}$ justifies investment in innovation reflects, in my view, this loss of judgmental capacity. ${ }^{80}$ Instead, the current structure of stock-based executive remuneration creates incentives for senior executives to allocate resources in ways that achieve "timely" boosts to stock prices that help to increase their take-home pay. ${ }^{81}$ There are other ways in which, depending on the industry in which the company operates, an executive can generate manipulative increases in stock prices; a prominent example is price-gouging in the

\footnotetext{
${ }^{76}$ Lazonick, Competitive Advantage on the Shop Floor; Lazonick, "The Theory of Innovative Enterprise."

${ }^{77}$ Hopkins and Lazonick, "The Mismeasure of Mammon."

${ }^{78}$ Lazonick and Shin, "Rebalancing Value Creation and Value Extraction."

79 Jensen, "Agency Costs of Free Cash Flow."

${ }^{80}$ See Carliss Y. Baldwin, "How Capital Budgeting Deters Innovation - and What To Do About It," Research Technology Management, 34, 6, 1991: 39-45; Clayton Christensen, Stephen P. Kaufman, Willy C. Shih, "Innovation Killers: How Financial Tools Destroy Your Capacity to Do New Things," Harvard Business Review, January 2008: 98-105.

81 Lazonick, "Taking Stock"; Hopkins and Lazonick, "The Mismeasure of Mammon."
} 
pharmaceutical industry. ${ }^{82}$ More generally, however, the stock buyback is a powerful tool at the disposal of corporate executives for manipulating the stock market for their personal gain. Yet buybacks manifest precisely the "disgorging" (as if it had been ill-gained by the corporation) of the so-called "free" cash flow that agency theory prescribes. So too, agency theory advocates stock-based pay to incentivize senior executives to engage in this financialized behavior. ${ }^{83}$

\section{Organizational integration}

Collective and cumulative, or organizational, learning about the technologies, markets, and competitors relevant to a particular industry is the foundation for generating the higher quality, lower cost goods and services that result in productivity growth ${ }^{84}$ Productivity is collective because one learns through the interaction with others in a hierarchical and functional division of labor. Productivity is cumulative because what the collectivity learns today provides the foundation for what it is capable of learning tomorrow. What I call "collective and cumulative careers" are essential for organizational learning, especially in industries that are technologically and organizationally complex. ${ }^{85}$ It is on the basis of higher levels of productivity generated by organizational learning that business enterprises can pay their valued employees higher wages on a sustainable basis. Organizational learning in turn depends on a "retain-and-reinvest" corporate resource-allocation regime in which senior executives make corporate resource-allocation decisions that, by retaining people and profits in the company, permit reinvestment in the productive capabilities that can generate competitive (high-quality, low-cost) products. ${ }^{86}$ Our research into the dynamics of innovative enterprise supports the hypothesis that, as part of a corporate resource-allocation regime that downsizes the U.S. labor force and distributes corporate cash to shareholders, stock buybacks are done at the expense of investments in collective and cumulative careers. The disappearance of this career employment in major business enterprises is central to the erosion of the American "middle class" over the past three decades. ${ }^{87}$ By legitimizing massive distributions of corporate cash to shareholders, MSV directly undermines the building of the organizational capabilities that are the essence of innovative enterprise.

\section{Financial commitment}

The cash flow that MSV calls "free" can deprive the business enterprise of the foundational finance for investment in innovative enterprise. Stock buybacks represent a withdrawal of internally controlled finance that could be used to support investment in the company's productive capabilities. For many of the largest repurchasers, dominant product-market positions based on past investments in innovation generate streams of profits that enable these companies to do billions of dollars in buybacks year after year without running low on cash. The ability of some companies to use their cash reserves, often leveraged by borrowed funds, to manipulate their stock prices places pressures to do large-scale buybacks on other companies whose "success" is measured by stock-price performance but whose cash flow is insufficient to support their buyback habits. Every once in a while, as documented in our research, a company that has done massive buybacks over a period of years hits a financial wall, at which point the billions of dollars that it wasted on buybacks are not available to support a process to restructure its accumulated capabilities to become innovative once again. ${ }^{88}$ The

\footnotetext{
82 Lazonick et al., "U.S. Pharma's Business Model."

${ }^{83}$ See Jensen and Murphy, "Performance Pay and Top Management Incentives."

84 Lazonick, "The Theory of Innovative Enterprise"; Lazonick et al., "Skill Development and Sustainable Prosperity."

85 Lazonick et al., "Skill Development and Sustainable Prosperity."

${ }^{86}$ Lazonick and O'Sullivan, "Maximizing Shareholder Value"; Lazonick, "Stock Buybacks.

87 Lazonick, "Labor in the Twenty-First Century": William Lazonick, Philip Moss, and Joshua Weitz, "The Equal Employment Opportunity Omission," Institute for New Economic Thinking Working Paper No. 53, December 5, 2016, at https://www.ineteconomics.org/research/research-papers/the-equal-employment-opportunity-omission.

88 Lazonick, "Everyone is paying the price for share buy-backs"; Lazonick, "The buyback boondoggle"; William Lazonick, "The Financialization of the US Corporation: What Has Been Lost, and How It Can Be Regained," Seattle University Law Review, 36, 2013: 857-908; Lazonick, "Labor in the Twenty-First Century."
} 
process of predatory value extraction that destroys innovative enterprise is irreversible. It must be stopped before it starts. 